\title{
Histological analysis of low-intensity laser therapy effects in peripheral nerve regeneration in Wistar rats $^{1}$
}

\author{
Avaliação histológica dos efeitos da laserterapia de baixa potência sobre os processos de \\ regeneração nervosa periférica em ratos Wistar
}

\author{
Cibele Nazaré da Silva CâmaraI, Marcus Vinicius Henriques Brito"I, Edvaldo Lima Silveira' ${ }^{\mathrm{III}}$, Diego Sá Guimarães da Silva ${ }^{\mathrm{IV}}$, \\ Vivian Roberta Ferreira Simões ${ }^{v}$, Roberto Waldesmand Farias Pontes ${ }^{v}$ \\ ${ }^{1}$ Research performed at Experimental Surgery Laboratory, Para State University (UEPA), Belem-PA, Brazil.

\begin{abstract}
${ }^{I}$ Master, Associate Professor, Department of Physiotherapy, UNAMA, Belem-PA, Brazil. Conception, design and scientific content of the study. Analysis and interpretation of data. Manuscript writing. Critical revision.

${ }^{\text {II }} \mathrm{PhD}$, Associate Professor, Department of Integrated Health, UEPA, Belem-PA, Brazil. Provided guidelines for the surgical interventions. Analysis and interpretation of data. Manuscript writing. Critical revision.

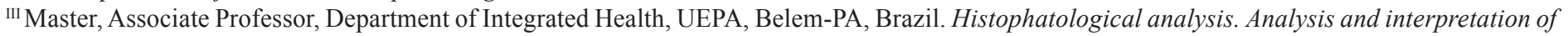
data.

${ }^{\text {IV }}$ Fellow of Psychology, Department of Psychology, UFPA, Belem-PA, Brazil. Technical procedures. Manuscript writing. Statistical analysis.

${ }^{\vee}$ Graduate student, Medical School, UEPA, Belem-PA, Brazil. Helped with technical procedures and collection of study informations.
\end{abstract}

\begin{abstract}
Purpose: Analyze the influence of low-intensity laser therapy in the sciatic nerve regeneration of rats submitted to controlled crush through histological analysis. Methods: Were used 20 Wistar rats, to analyze the influence of low-intensity laser therapy in the sciatic nerve regeneration, where the injury of the type axonotmesis was induced by a haemostatic clamp Crile (2nd level of the rack). The animals were randomly distributed in 2 groups. Control group $(\mathrm{CG} \mathrm{n}=10)$ and Laser group (LG $\mathrm{n}=10)$. These were subdivided in 2 subgroups each, according to the euthanasia period: (CG14 $-\mathrm{n}=5$ and CG2 $1-\mathrm{n}=5)$ and $(\mathrm{LG} 14-\mathrm{n}=5$ and LG21 $-\mathrm{n}=5)$. At the end of treatment, the samples were removed and prepared for histological analysis, where were analyzed and quantified the following findings: Schwann cells, myelinic axons with large diameter and neurons. Results: In the groups submitted to low-intensity laser therapy, were observed an increase in the number of all analyzed aspects with significance level. Conclusion: The irradiation with low intensity laser $(904 \mathrm{~nm})$ influenced positively the regeneration of the sciatic nerve in Wistar rats after being injured by crush (axonotmesis), becoming the nerve recovery more rapid and efficient.
\end{abstract}

Key words: Laser Therapy, Low-Level. Nerve Regeneration. Rats, Wistar.

\section{RESUMO}

Objetivo: Verificar a influência da terapia com laser de baixa potência na regeneração histológica do nervo ciático de ratos submetidos à neuropraxia controlada. Métodos: Foi utilizada a amostra de 20 ratos da linhagem Wistar, para verificar a influência da terapia com laser de baixa intensidade na regeneração nervosa periférica, onde a lesão do tipo axoniotmese foi induzida por meio de preensão com pinça hemostática de Crile. Os animais foram distribuídos randomicamente dois grupos. Grupo controle (CG n = 10), e Grupo laser ( $\mathrm{LG} n=10)$. Cada um destes grupos foi subdividido em dois subgrupos dependendo do período da eutanásia: $(\mathrm{CG} 14-\mathrm{n}=5 \mathrm{e}$ CG21 - n = 5) e (LG14 - n= 5 e LG21 - n=5). Ao final do tratamento, amostras do nervo foram retiradas e analisadas histologicamente, nas quais foi adotado na pesquisa a análise do número de neurônios, de células de Schwann (CS) e de axônios mielínicos de grande diâmetro. Resultados: Nos grupos submetidos à terapia com laser de baixa potencia foi observado aumento do número de todos os aspectos analisados com diferença estatisticamente significante. Conclusão: A irradiação com o laser de baixa intensidade $(904 \mathrm{~nm})$ influenciou positivamente na regeneração do nervo ciático de ratos da linhagem Wistar pós neuropraxia controlada (axonotmese), tornando a recuperação nervosa mais rápida e eficiente.

Descritores: Terapia a Laser de Baixa Intensidade. Regeneração Nervosa. Ratos Wistar. 


\section{Introduction}

Peripheral nerves are structures frequently affected by traumatic lesions, as total or partial crush, compression, stretch, avulsion and section that cause the interruption of the transmission of nerve impulses, the reduction or lost of sensitivity and motility in the innerved area ${ }^{1}$.

According to Pachioni et al. ${ }^{2}$ this type of lesion if not adequately treated may provoke a significant deficit, with damages not only in the quality of life of patients, but also to the state system in cases of premature retirement due to functional incapacity.

Therefore, numerous studies have searched for the optimization of the regeneration of peripheral nerves utilizing different techniques, always aiming to abbreviate the period of recovery of the injured nerve $\mathrm{e}^{3,4}$.

Thus, the model of crush lesion has been adopted by several authors that emphasize the fact that the crush preserves, at least in part, the nerve structure, facilitating its regeneration, and for not demonstrating the necessity of realizing a suture, what implicates in previous training in microsurgical techniques and the availability of adequate instrumental and material, in general, with high $\operatorname{cost}^{1}$.

Studies on molecular biology have sustained that the laser therapy increases the rates of nerve regeneration, reinnervation and neuronal survival after the rupture of axons ${ }^{5}$.

The molecular base that would justify the effectiveness of the laser therapy on the nerve regeneration has not been clear yet. However studies suggest that low-intensity laser therapy improves function, accelerates regenerative process, and decreases inflammatory response in the nerve. It can also promote a higher metabolism in neurons and a better ability to produce myelin ${ }^{6}$.

Among several generators of laser therapy, we may highlight Arsenate-Gallium Laser (As-Ga), which is already known to accelerate the recovery of peripheral nerves ${ }^{7}$. The results can vary depending on the pattern of the lesion induced and the lasers range ${ }^{8}$.

The objective of this study was to analyze the influence of Low-intensity laser therapy in the sciatic nerve regeneration of rats submitted to controlled crush through histological analysis.

\section{Methods}

All animals of the present research were cared according to the norms of the Brazilian School of Animal Experimentation (COBEA) and the current national legislation for vivisection (Federal Law 11,794 on October 9th, 2008), being the research project approved by the Committee of Ethics in Research with Animals - CEPAN at Evandro Chagas Institute, Belem-PA.

An experimental analytic study assay type clinical and randomized controlled was realized (systematic randomization), and the capacity of peripheral nerve regeneration was evaluated with Wistar rats submitted to axonotmesis, after the application of Low-intensity laser therapy (Ga-As).

Therefore, 20 male adult Wistar rats were utilized, with body weight varying between 250 and 350 grams. The animals were maintained in individual plastic cages in adequate sanitary conditions, and put in a temperature-controlled environment $\left(22^{\circ} \mathrm{C}\right)$, provided with water and standardized food (ration for rodents) ad libitum.

The animals were randomly distributed according to the treatment and the euthanasia period:

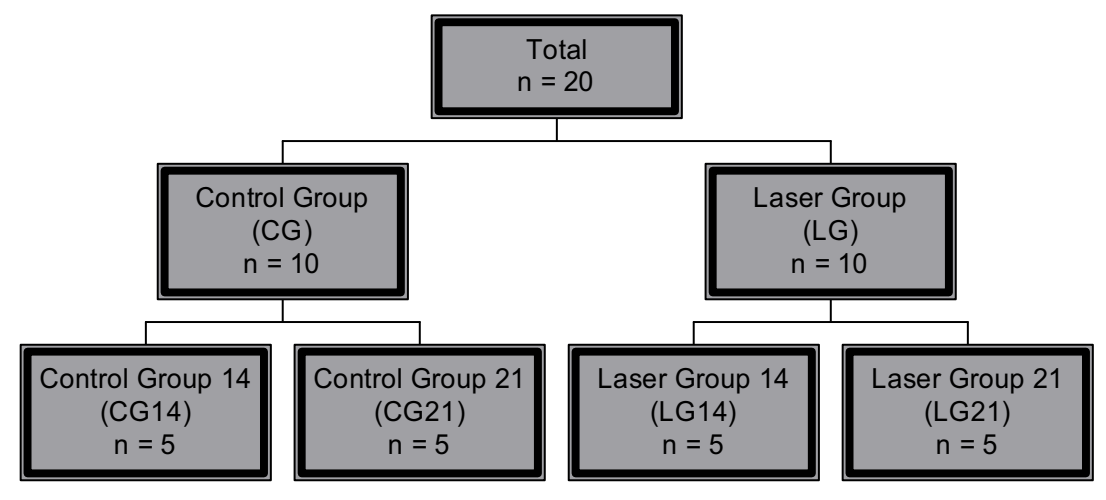

The animals were anesthetized intraperitoneal with solutions of ketamine chloridrate, $(80 \mathrm{mg} / \mathrm{Kg})$, Xylazine hydrochloride $2 \%(10 \mathrm{mg} / \mathrm{Kg})$ and atropine $(0,05 \mathrm{mg} / \mathrm{Kg})$. They were maintained in ventral decubitus, and the epilating of the caudal region was realized, followed by local anti-sepsis with polyvinylpyrrolidone - iodine (PVPI) solution. The incision was performed on the right side to be operated, and transversely, in

The sciatic nerve was exposed by a longitudinal posterior-lateral incision since the great trochanter until the region next to the femur lateral condyles. Subsequently, a rhombic dissection between the maximum gluteus and quadriceps muscles was carried out allowing the complete vision of the nerve (Figure 1). 


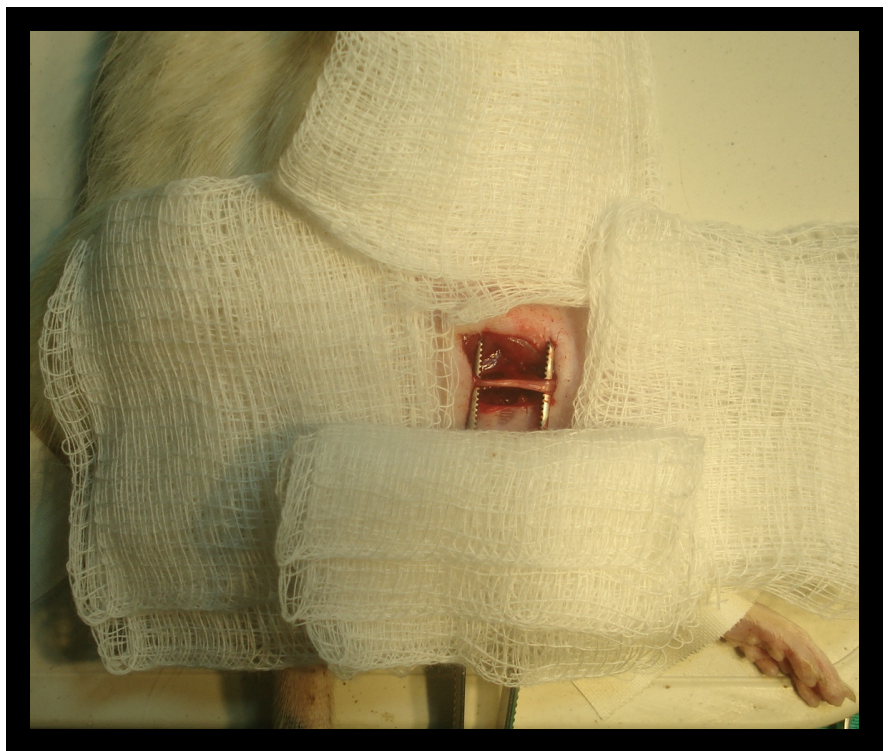

FIGURE 1 - Dissection of rat's sciatic nerve.

Source: Fieldwork archive, 2010.

A haemostatic clamp Crile, in which the second level of the rack was utilized for maintaining the nerve crush, realized, then, the crush. The same was maintained closed in order to crush the nerve during 30 seconds, considering that the same was approached in a standardized way around $0.5 \mathrm{~cm}$ distal at its emergence. Then, the surgical closure of the region was realized with Mononylon 4-0 threads.

To treat animals, was utilized Arsenate of Gallium Laser (GaAs), brand $\mathrm{KLD}^{\circledR}$, model LASER I R (Figure 2), with the extension of wave of $904 \mathrm{~nm}, 26.3 \mathrm{~mW}$ power, beam area of $0.63 \mathrm{~cm}^{2}$, penetration of $1.5 \mathrm{~cm}$, in the pulsed form.

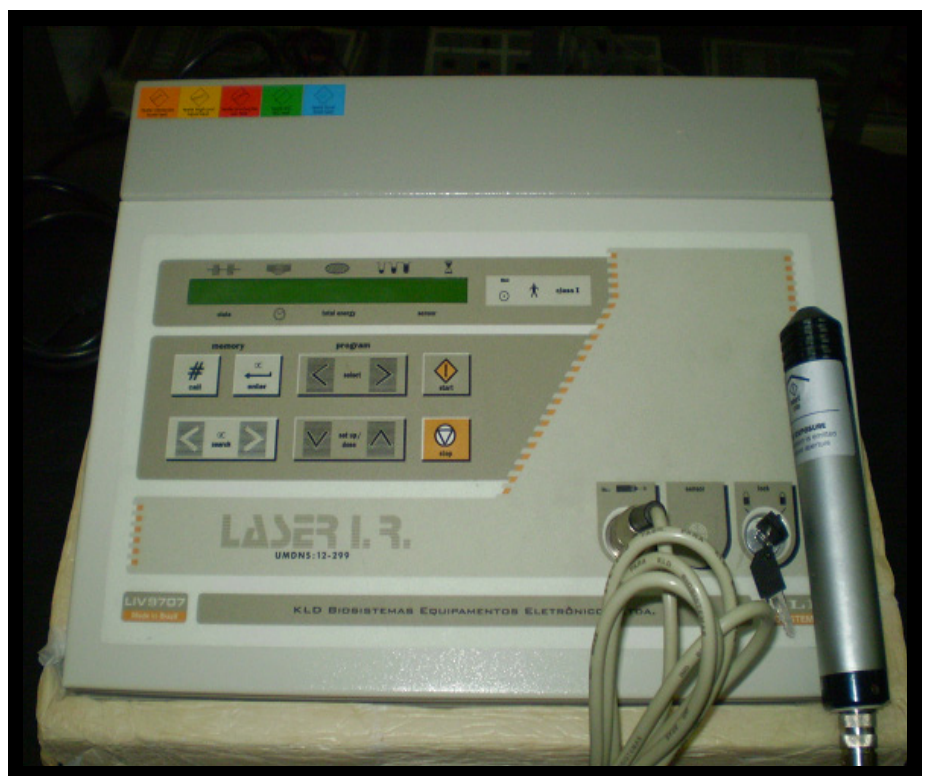

FIGURE 2 - GaAs Laser equipment, extension of wave of $904 \mathrm{~nm}$. Source: Fieldwork archive, 2010.
The application form occurred through exact transcutaneous method and in contact (for reducing the reflection) with power density of $4 \mathrm{~J} / \mathrm{cm}^{2}$, potential density of $0.0413 \mathrm{~W} / \mathrm{cm}^{2}$ and the duration of time of 32 seconds of application in each point, where the same ones were marked around the surgical incision, being three points of each side of it, totaling, then, six points (Figure 3).

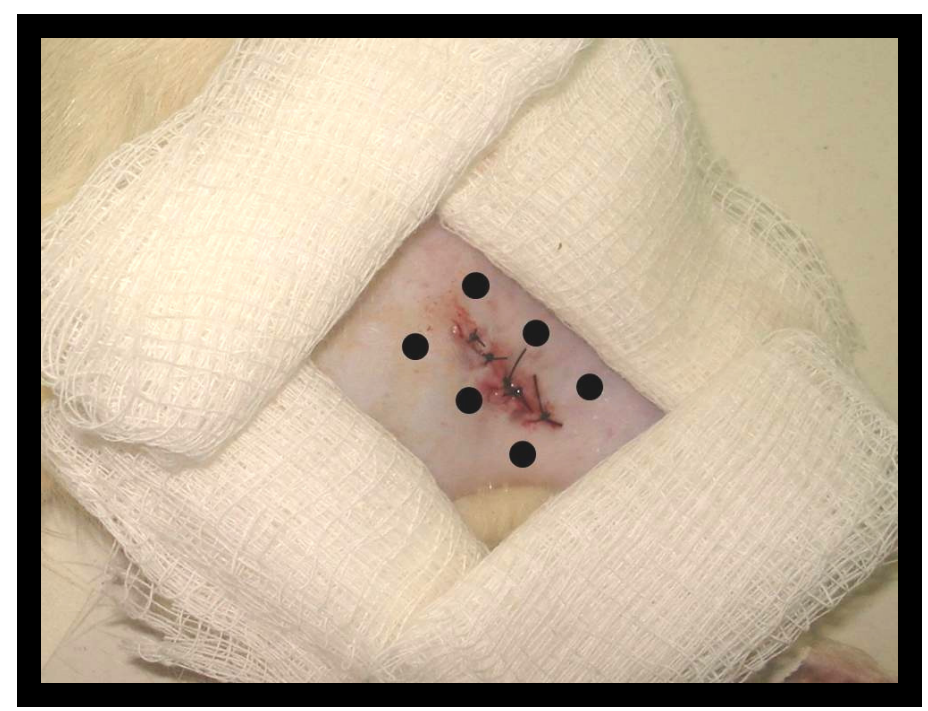

FIGURE 3 - Laser application points through transcutaneous method. Source: Fieldwork archive, 2010.

The Laser therapy was initiated on the post-surgical first day, where all the animals in the laser group were submitted to the same procedure with applications once a day during 14 and 21 days, respectively.

On the 14th day, the first 10 animals were submitted to euthanasia by an anesthetic overdoses, after that a sciatic nerve part was removed from the right hind leg of 5 animals from each subgroup (5 CG, $5 \mathrm{LG}$ ), totaling 10 samples. The same procedure was performed on the 21 st day according to the subgroups that were submitted to treatment during 21 days ( $5 \mathrm{CG}, 5 \mathrm{LG}$ ).

Immediately after the material collection, the samples were prepared for histopathological analysis realized in the Central Laboratory of Pathology of the Department of Pathological Anatomy at João de Barros Barreto University Hospital (HUJBB). The blades were examined and analyzed through the utilization of an optical microscope, with an objective lens with 40X; 15 microscopic fields from those were analyzed and quantified the following histological findings: Schwann cells, myelinic axons with large diameter and neurons.

For the statistic evaluation, BioEstat version 5.0 software was utilized, and $95 \%$ as the level of significance, $\alpha=0.05$ as level of decision for the rejection hypothesis of nullity, were previously established. Data from the histological analysis were submitted to statistic tests through variance analysis (ANOVA) with Tukey's post-test, being the results with $P$ smaller than 0.05 considered significant. The results were expressed as average \pm standard deviation among the control and laser therapy groups on the post-surgical 14th and 21st day. 


\section{Results}

TABLE 1 - Neurons in histological findings at groups in 14 and 21 days.

\begin{tabular}{ccccc}
\hline \hline Groups & $\begin{array}{c}\text { Control group } \\
\text { (14 days) }\end{array}$ & $\begin{array}{c}\text { Laser Group } \\
\text { (14 days) }\end{array}$ & $\begin{array}{c}\text { Control group } \\
\text { (21 days) }\end{array}$ & $\begin{array}{c}\text { Laser Group } \\
\text { (21 days) }\end{array}$ \\
\hline Rat 1 & 164 & 313 & 393 & 502 \\
Rat 2 & 187 & 301 & 302 & 561 \\
Rat 3 & 136 & 297 & 397 & 446 \\
Rat 4 & 151 & 314 & 380 & 473 \\
Rat 5 & 182 & 285 & 393 & 423 \\
Total & $\mathbf{8 2 0}$ & $\mathbf{1 5 1 0}$ & $\mathbf{1 9 6 5}$ & $\mathbf{2 4 0 5}$ \\
Mean + SD & $164.0+21.2$ & $302.0+12.0$ & $373.0+40.2$ & $481.0+53.6$ \\
(Min - Max) & $(136-187)$ & $(285-314)$ & $(302-397)$ & $(423-561)$ \\
Anova P value & \multicolumn{2}{c}{$(\mathbf{p})=\mathbf{0 . 0 0 0 6}$} & $\mathbf{0 . 0 0 7 5}$ \\
\hline \hline
\end{tabular}

Source: Research data (2010)

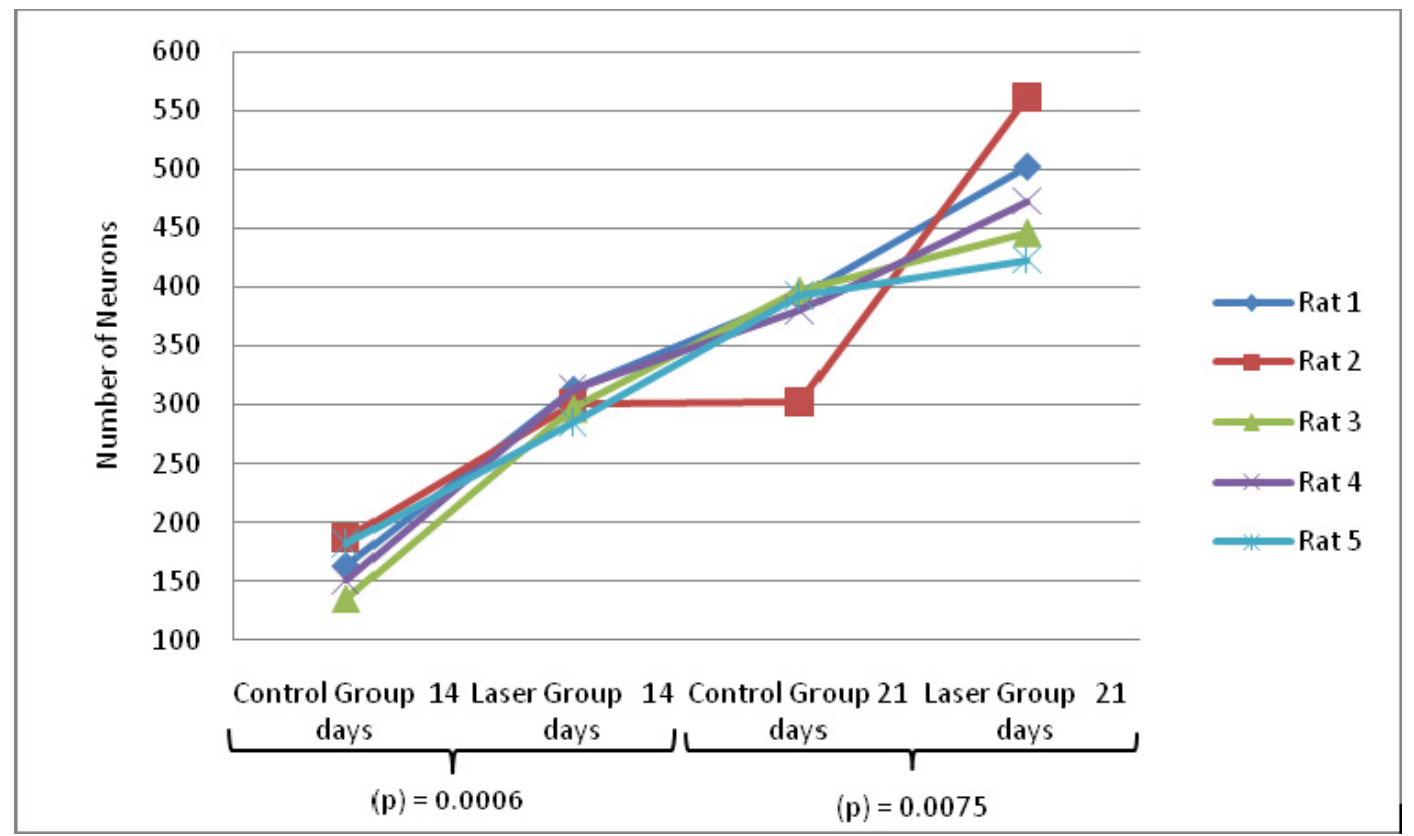

FIGURE 4 - Neurons in histological findings at groups in 14 and 21 days. Source: Fieldwork archive, 2010. 
TABLE 2 - Presence of Schwann cells in the histological findings at groups in 14 and 21 days.

\begin{tabular}{|c|c|c|c|c|}
\hline Groups & $\begin{array}{c}\text { Control group } \\
\text { (14 days) }\end{array}$ & $\begin{array}{c}\text { Laser Group } \\
\text { (14 days) }\end{array}$ & $\begin{array}{c}\text { Control group } \\
\text { (21 days) }\end{array}$ & $\begin{array}{c}\text { Laser Group } \\
\text { (21 days) }\end{array}$ \\
\hline Rat 1 & 12 & 24 & 21 & 30 \\
\hline Rat 2 & 7 & 31 & 18 & 43 \\
\hline Rat 3 & 4 & 40 & 23 & 34 \\
\hline Rat 4 & 9 & 32 & 17 & 33 \\
\hline Rat 5 & 8 & 27 & 21 & 39 \\
\hline Total & 40 & 110 & 100 & 183 \\
\hline Mean + SD & $8.0+2.9$ & $30.8+6.1$ & $20.0+2.4$ & $35.8+5.2$ \\
\hline (Min - Max $)$ & $(4-12)$ & $(24-40)$ & $(17-23)$ & $(30-43)$ \\
\hline Anova $P$ value & \multicolumn{2}{|c|}{$(p)=0.0002$} & \multicolumn{2}{|c|}{$(p)=0.0005$} \\
\hline
\end{tabular}

Source: Research data (2010)

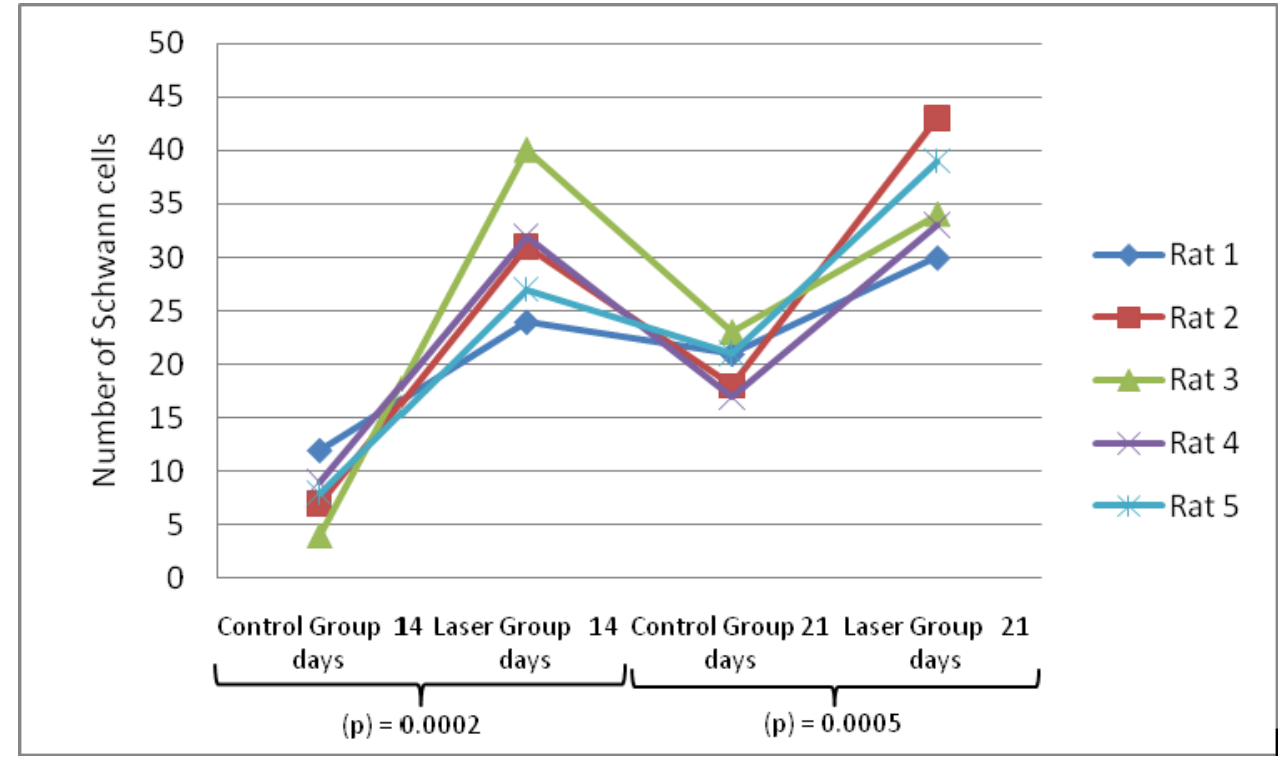

FIGURE 5 - Presence of Schwann cells in the histological findings at groups in 14 and 21 days. Source: Fieldwork archive, 2010.

TABLE 3 - Presence of myelinic axons of large diameter in the histological findings at groups in 14 and 21 days.

\begin{tabular}{ccccc}
\hline Groups & $\begin{array}{c}\text { Control Group } \\
(\mathbf{1 4} \text { dias })\end{array}$ & $\begin{array}{c}\text { Laser Group } \\
(\mathbf{1 4} \text { dias })\end{array}$ & $\begin{array}{c}\text { Control Group } \\
(\mathbf{2 1} \text { dias })\end{array}$ & $\begin{array}{c}\text { Laser Group } \\
(\mathbf{2 1} \text { dias })\end{array}$ \\
\hline \hline Rat 1 & 5 & 9 & 8 & 12 \\
Rat 2 & 7 & 14 & 10 & 16 \\
Rat 3 & 4 & 11 & 7 & 15 \\
Rat 4 & 8 & 12 & 10 & 19 \\
Rat 5 & 6 & 8 & 9 & 13 \\
Total & $\mathbf{3 0}$ & $\mathbf{5 4}$ & $8.8+1.3$ & $\mathbf{7 5}$ \\
Mean + SD & $6.0+1.6$ & $10.8+2.4$ & $(7-10)$ & $(12-19)$ \\
(Min - Max $)$ & $(4-8)$ & $(8-14)$ & $(\mathbf{p})=\mathbf{0 . 0 0 2 2}$ \\
Anova P value & $(\mathbf{p})=\mathbf{0 . 0 0 5 8}$ & &
\end{tabular}

Source: Research data (2010) 


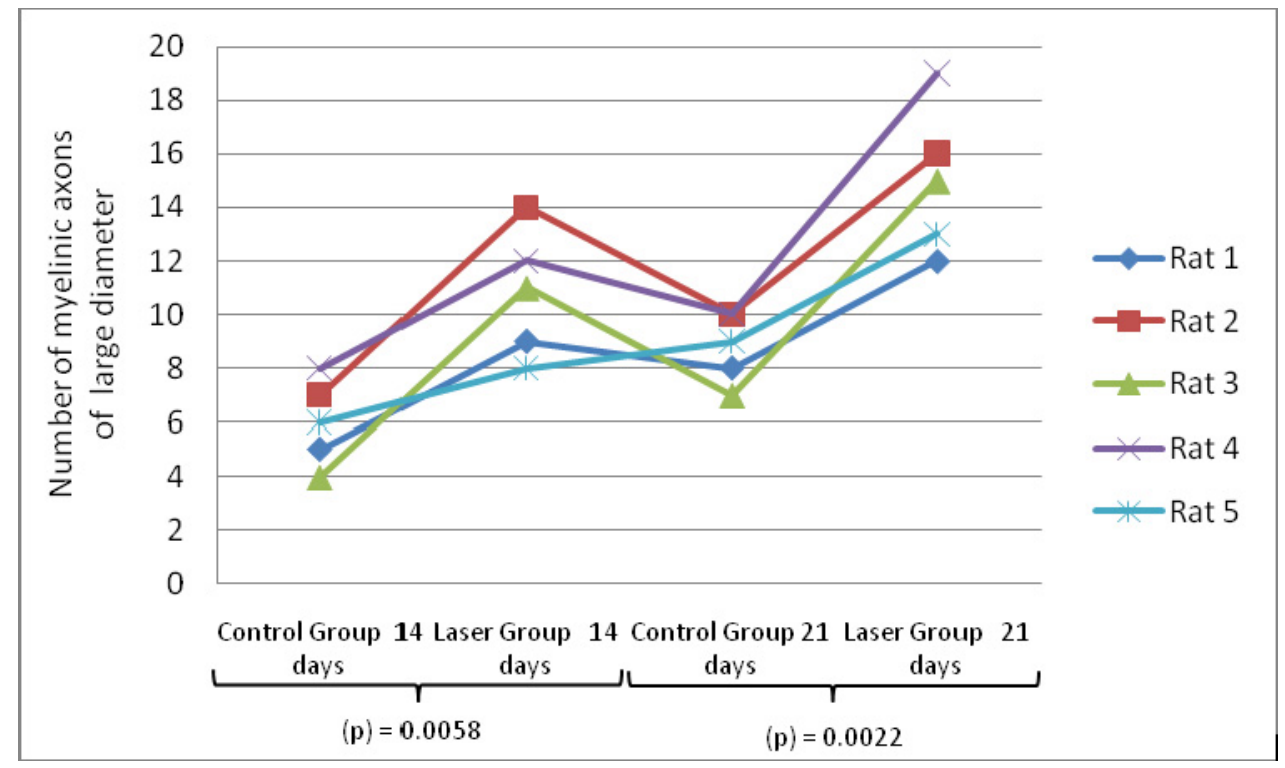

FIGURE 6 - Presence of myelinic axons of large diameter in the histological findings at groups in 14 and 21 days. Source: Fieldwork archive, 2010.

\section{Discussion}

Although little is known on the role of the laser in the treatment of peripheral nerve lesions, the irradiation with laser is very utilized for treating a variety of pathological conditions of the system of skeletal-muscle, including peripheral nerves.

The irradiation with laser interfere somehow in the nerve function, according to some demonstrations that evidence that there is a reduction of latency time and an increase in the speed of the nerve conduction. There are still some experimental evidences that a laser has a positive effect in the regeneration of injured nerves ${ }^{9}$. The use of AlGaAs laser $(660 \mathrm{~nm})$ provided significant changes to the morphometrically assessed area of the myelin sheath ${ }^{8}$.

In the present research, we observed a significant difference among the groups for the proliferation of neurons and Schwann cells over 14 and 21 days of treatment through laser therapy, making the treatment efficiency through this resource, even in a short period of time, statistically proved. Immunohistochemical staining in the laser-treated group for 21 consecutive days showed an increased total number of axons and better quality of the regeneration process, due to an increased number of large-diameter axons, compared to the non-irradiated control group. The study suggests that postoperative LPLI enhances the regenerative processes of peripheral nerves after complete transection and anastomosis ${ }^{10}$.

This laser effect in the regeneration is probably mediated by growth factors of local action, but the possibility that the laser also stimulates the liberation of chemical mediators and chemiotaxics may not be discarded, which accelerate the production of axoplasm in the cellular body ${ }^{9}$.

There are evidences, in clinical and experimental researches, that one of the laser effects is to increase the nerve function, preventing the formation of wounds, elevating the metabolism of neurons and increasing the capacity of myelin production. The fact that the laser therapy is not invasive in the ability of irradiating injured nerves without surgical interventions has been useful ${ }^{11}$.

Studies by Mohammed et al. ${ }^{6}$ have demonstrated the laser potential with low intensity, which by specimens collected from animals in two experimental groups showed significant variation between control and treated animals when examined histopathologically. The treated animals showed better results regarding the two factors studied in the experiment: larger diameter of nerve fibers and longer inter-nodal distance. These findings suggest better nerve function, acceleration of the regenerative process, and less inflamatory response (less debris and macrophages accumelation) and less swelling of paranodal areas after low-level laser therapy (LLLT). LLLT may promoted higher metabolism in neurons and a better ability to produce myelin 6 .

Studies by Ehrlicher et al. ${ }^{12}$ have demonstrated the laser potential with low intensity, which by being applied in neurons in culture, the same have proliferated and changed the dislocation of the growth cone of neurons that suffered total transaction. In addition to these explanations, there are some evidences demonstrating that the laser may positively interfere in the peripheral nerve regeneration, influencing the production of trophic proteins as the basic fibroblastic growth factor (bFGF) ${ }^{13}$.

Therefore, the present study highlighted the effectiveness of As-Ga laser for the treatment of peripheral nerve lesions, utilizing the histological analysis for proving such effect, being necessary in order to have a better understanding of nerve regeneration processes, and new studies that may evaluate growth factors as the basic fibroblastic growth factor, neuronal growth factor (NGF), GAP-43 (protein associated with the axonal peripheral regeneration). 


\section{Conclusion}

The irradiation with low intensity laser (904nm) influenced positively the regeneration of the sciatic nerve in Wistar rats after being injured by crush (axonotmesis), becoming the nerve recovery more rapid and efficient.

\section{References}

1. Monte-Raso VV, Barbieri CH, Mazzer N, Fazan VPS. Os efeitos do ultra-som terapêutico nas lesões por esmagamento do nervo ciático de ratos: análise funcional da marcha. Rev Bras Fisioter. 2006;10(1):113-9. 2. Pachioni CAS, Mazzer N, Barbieri CH, Fazan VPS, Padovanis CR, Moro CA, Silva CAA. Lesão por esmagamento do nervo isquiático de ratos: estudo da vascularização. Acta Ortop Bras. 2006;14(4):203-7.

3. Girard C, Liu S, Cadepond F, Adams D, Lacroix C, Verleye M, Gillardin JM, Baulieu EE, Schumacher M, Schweizer-Groyer G. Etifoxine improves peripheral nerve regeneration and functional recovery. Proc Natl Acad Sci USA. 2008;105(51):20505-10.

4. Mehanna A, Mishra B, Kurschat N, Schulze C, Bian S, Loers G, Irintchev A, Schachner M. Polysialic acid glycomimetics promote myelination and functional recovery after peripheral nerve injury in mice. Brain. 2009;132(Pt 6):1449-62.

5. Snyder SK, Byrnes KR, Borke RC, Sanches A, Anders JJ. Quantitation of calcitonin gene-related peptide mRNA and Neuronal cell death in facial motor nuclei following axotomy and $633 \mathrm{~nm}$ low power laser. Lasers Surg Med. 2002;31(3):216-22.
6. Mohammed IF, Al-Mustawfi N, Kaka LN. Promotion of regenerative processes in injured peripheral nerve induced by low-level laser therapy. Photomed Laser Surg. 2007;25(2):107-11.

7. Camargo VM, Costa J, André ES. Estudo comparativo entre dois tipos de raio laser de baixa potência e seus respectivos efeitos sobre a regeneração nervosa periférica. Fisioter Mov. 2006;19(2):127-34.

8. Dos Reis FA, Belchior AC, de Carvalho Pde T, da Silva BA, Pereira DM, Silva IS, Nicolau RA. Effect of laser therapy $(660 \mathrm{~nm})$ on recovery of the sciatic nerve in rats after injury through neurotmesis followed by epineural anastomosis. Lasers Med Sci. 2009;24(5):741-7.

9. Endo C, Barbieri CH, Mazzer N, Fasan, VS. A laserterapia de baixa intensidade acelera a regeneração de nervos periféricos. Acta Ortop. Bras. 2008;16(5):305-10

10. Shamir MH, Rochkind S, Sandbank J, Alon M. Double-blind randomized study evaluating regeneration of the rat transected sciatic nerve after suturing and postoperative low-power laser treatment. J Reconstr Microsurg. 2001;17(2):133-7.

11. Carvalho PTC, Mazzer N, Dos Reis FA, Belchior ACG, Silva IS. Analysis of the influence of low-power HeNe laser on the healing of skin wounds in diabetic and non-diabetic rats. Acta Cir Bras. 2006;21(3):177-83.

12. Ehrlicher A, Betz T, Stuhrmann B, Koch D, Milner V, Raizen MG, Käs J. Guiding neuronal growth with light. Proc Nac Acad Sci. 2002;99(25):16024-8.

13. Shen N, Zhu J. Experimental study a direct current electrical field to promote peripheral nerve regeneration. J Reconstr Microsurg. 1995;11(3):189-93.

\section{Correspondence:}

Cibele Nazaré da Silva Câmara

Rua Jerônimo Pimentel, 426/402

66055-000 Belém-PA Brasil

Phone: (55 91)3222-8292 / 8148-9060

camaracibele@yahoo.com.br

Conflict of interest: none Financial source: none

Received: July 06, 2010

Review: September 13, 2010

Accepted: October 19, 2010 